\title{
Assessment of genetic diversity of a native population of Eplingiella fruticosa: a plant with therapeutic potential
}

\author{
D.C. Silva ${ }^{1}$, L.E.C. Diniz ${ }^{2}$, A.F. Blank ${ }^{1}$, D.A.C. Nizio' ${ }^{1}$ J.A.O. Pinto ${ }^{1}$, \\ K.L.G. Pereira ${ }^{1}$ and M.F. Arrigoni-Blank ${ }^{1}$ \\ ${ }^{1}$ Laboratório de Recursos Genéticos Vegetais e Óleos Essenciais, \\ Programa de Pós-Graduação em Agricultura e Biodiversidade, \\ Universidade Federal de Sergipe, São Cristóvão, SE, Brasil \\ ${ }^{2}$ Laboratório de Biologia Molecular, Embrapa Tabuleiros Costeiros, \\ Aracaju, SE, Brasil \\ Corresponding author: M.F. Arrigoni-Blank \\ E-mail: fatima.blank@gmail.com
}

Genet. Mol. Res. 16 (3): gmr16039749

Received June 12, 2017

Accepted August 8, 2017

Published August 17, 2017

DOI http://dx.doi.org/10.4238/gmr16039749

Copyright (C) 2017 The Authors. This is an open-access article distributed under the terms of the Creative Commons Attribution ShareAlike (CC BY-SA) 4.0 License.

ABSTRACT. Eplingiella fruticosa (Salzm. ex Benth.) Harley \&
J.F.B. Pastore, ex Hyptis fruticosa Salzm. ex Benth. is an aromatic and
medicinal plant of the family Lamiaceae, found mainly in regions with
intense anthropic activity. Information on the genetic diversity of this
species is scarce. However, it can be assessed using molecular markers
that identify the level of diversity among phenotypically identical
individuals. The present study aimed to characterize the genetic
diversity of a native population of E. fruticosa from the State of Sergipe
using ISSR molecular markers. Samples of 100 plants were collected in
11 municipalities of the State of Sergipe and analyzed using eight ISSR
primers, resulting in 72 informative bands. The cluster analysis obtained
using the neighbor joining method resulted in three groups: Group I
consisted of 50 plants, mainly from the municipalities of Areia Branca,
Estância, Japaratuba, Moita Bonita, Pirambu, and Salgado; Group II was

Genetics and Molecular Research 16 (3): gmr16039749 
formed by 21 plants, with nine representatives from the municipality of Itaporanga d'Ajuda and 13 representatives from other municipalities; Group III was composed by 29 plants, being represented mainly by the municipalities of Malhada dos Bois and São Cristóvão. The smallest genetic distance occurred between plants EPF94 and EPF96 (0.250), and the greatest distance occurred between plants EPF50 and EPF96 $(0.9778)$. The Shannon index had a mean value of 0.42 , and diversity was considered moderate. Heterozygosity had a mean value of 0.267 and was considered low. Polymorphic information content (0.253) was considered moderately informative. Genetic diversity of $E$. fruticosa plants was intermediate, and the results of the present study can assist in the conservation and use of the genetic resources of this species.

Key words: Medicinal plant; Genetic variability; Conservation program; ISSR

\section{INTRODUCTION}

Eplingiella fruticosa (Salzm. ex Benth.) Harley \& J.F.B. Pastore, ex Hyptis fruticosa Salzm. ex Benth. is an aromatic plant of the family Lamiaceae, endemic to Brazil, known as "alecrim-de-vaqueiro". Besides being popularly used as an anti-inflammatory plant using the infusion of its leaves, the antitumor properties of E. fruticosa were identified by alcoholic extracts of the leaves (de Lima et al., 2013). Furthermore, the essential oil of this species has antinociceptive properties and induces arterial hypotensive effect (Menezes et al., 2007; Santos et al., 2007).

E. fruticosa is found mainly on the northeast coast of Brazil, in regions of intense agricultural activity expansion, native vegetation deforestation, and habitat fragmentation. Thus, the narrowing of the genetic variability may occur, which can lead to the extinction of the species and consequently to the loss of a potential source of useful molecules/compounds (Dobeš et al., 2017).

The biological properties of medicinal and aromatic plants are often related to the chemical composition of the essential oil, which may vary, even within the species. The study on the chemical diversity of essential oils is a strategy to characterize aromatic plants phenotypically. However, geo-climatic factors affect the chemical constitution of the essential oil, which hinders the study on how much of this variation is related to genetics (Sampaio et al., 2016; Santos et al., 2016).

To know the genetic variability, studies that directly assess the genetic content of the species should be carried out. This is because the genetic content is little influenced by the environment and can provide useful information for the management of the species and the development of strategies for the conservation of genetic resources (Celestino et al., 2015; Baruah et al., 2017). Since it is an aromatic species with medicinal potential and found in areas of intense anthropic activity, it is necessary to obtain information on the genetic diversity of natural populations of $E$. fruticosa, which may guide subsequent stages of conservation and use of this species (Alves et al., 2016; Brito et al., 2016).

Studies on genetic variability often use DNA molecular markers. Among the main molecular markers, ISSR (inter-simple sequence repeat) have arbitrary character, high

Genetics and Molecular Research 16 (3): gmr16039749 
reproducibility, and can characterize the genetic diversity of the species without prior knowledge of genome (Erbano et al., 2015; El-Amin and Hamza, 2016). ISSR markers have been used to identify the genetic variability among wild individuals of Satureja rechingeri (Hadian et al., 2015), to molecularly characterize and to detect genetic variations between accessions of Thymus sp (Yousefi et al., 2015), and to discriminate species of the genus Ocimum (Kumar et al., 2016), all of them belonging to the family Lamiaceae, assisting in the characterization of the existing genetic variability and conservation of the species studied.

Despite the studies on the chemical characterization of the essential oil of E. fruticosa in specific locations (Menezes et al., 2007; Silva et al., 2008; Franco et al., 2011a,b), no reports on the genetic variability by molecular markers for this species are available in the literature. Thus, the objective of the present study was to characterize the genetic diversity of a native population of E. fruticosa of the State of Sergipe using ISSR molecular markers.

\section{MATERIAL AND METHODS}

\section{Plant material}

Young leaves of 100 E. fruticosa plants were collected in 11 municipalities in the State of Sergipe, Brazil (Figure 1). Table 1 shows the identification and location of the 100 plants studied. After collection, leaves were stored at $-80^{\circ} \mathrm{C}$ for subsequent DNA extraction.

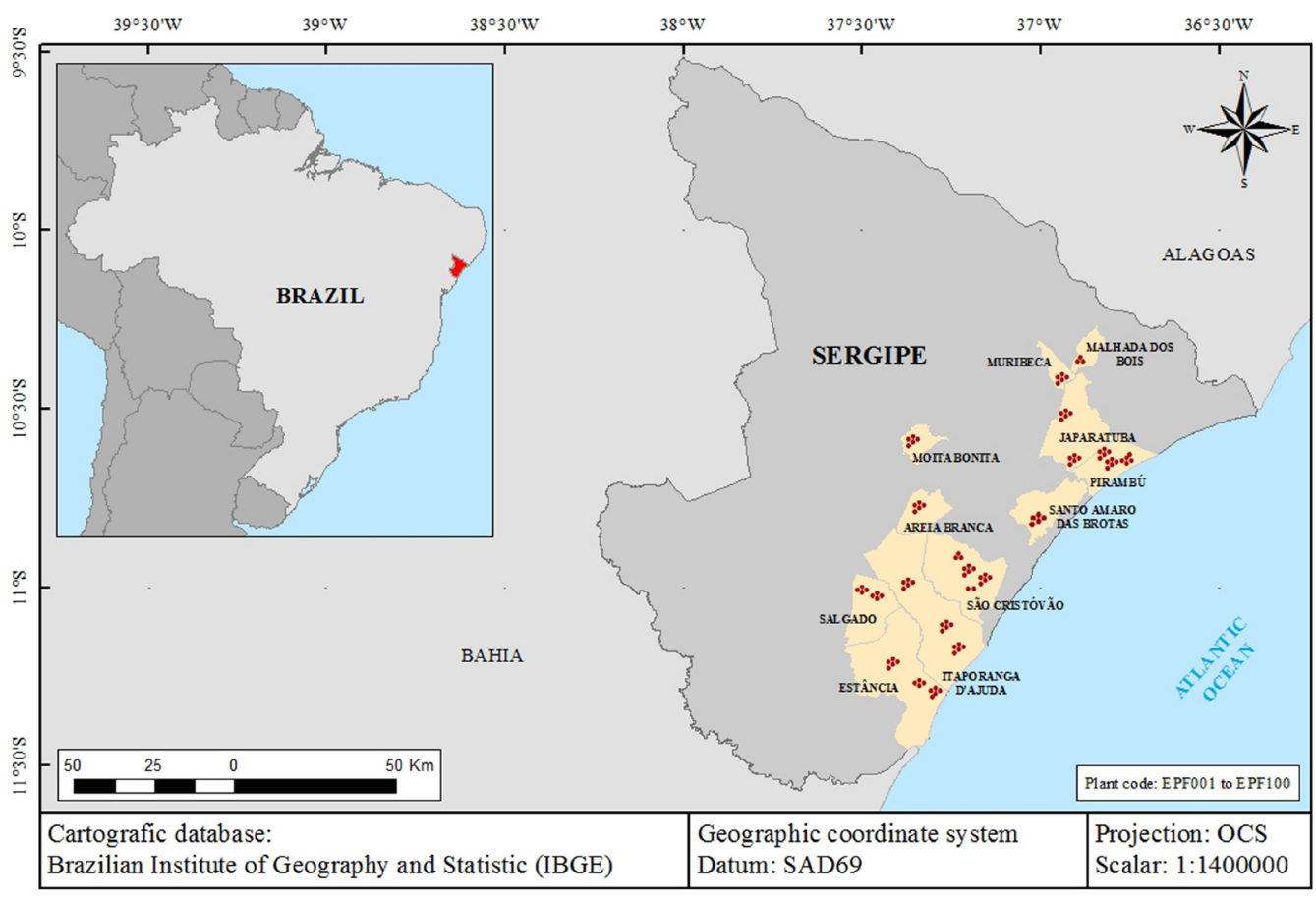

Figure 1. Location of the collection points of 100 plants of Eplingiella fruticosa in the State of Sergipe, Brazil.

Genetics and Molecular Research 16 (3): gmr16039749 
Table 1. Identification and origin of Eplingiella fruticosa plants collected in the State of Sergipe, Brazil.

\begin{tabular}{|c|c|c|c|}
\hline Plant code & $\mathrm{N}$ & Origin (Municipality) & Georeferenced information \\
\hline EPF01-05 & 5 & Areia Branca & $\begin{array}{l}10^{\circ} 46^{\prime} 03.4^{\prime \prime} \mathrm{S} 37^{\circ} 21^{\prime} 15.7^{\prime \prime} \mathrm{W} ; 10^{\circ} 46^{\prime} 14.8^{\prime \prime} \mathrm{S} 37^{\circ} 21^{\prime} 18.3^{\prime \prime} \mathrm{W} ; 10^{\circ} 46^{\prime} 12.6^{\prime \prime} \mathrm{S} 37^{\circ} 21^{\prime 2} 2.6^{\prime \prime} \mathrm{W} ; 10^{\circ} 46^{\prime} 10.2^{\prime \prime} \mathrm{S} 37^{\circ} 21^{\prime} 19.9^{\prime \prime} \mathrm{W} ; 10^{\circ} 46^{\prime} 12.2^{\prime \prime S} \\
37^{\circ} 21^{\prime} 17.6^{\prime \prime} \mathrm{W}\end{array}$ \\
\hline EPF06-19 & 14 & Estância & 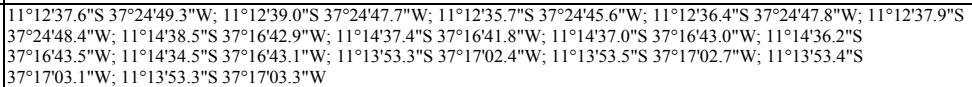 \\
\hline EPF20-34 & 15 & Itaporanga d'Ajuda & 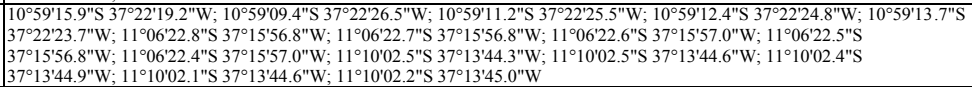 \\
\hline$\overline{\text { EPF35-44 }}$ & 10 & Japaratuba & 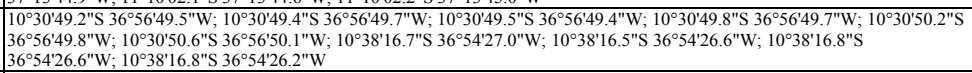 \\
\hline EPF45-47 & 3 & Malhada dos Bois & $10^{\circ} 21^{\prime} 36.1^{\prime \prime S} 36^{\circ} 54^{\prime 2} 28.1^{\prime \prime} \mathrm{W} ; 10^{\circ} 21^{\prime} 35.5^{\prime \prime} \mathrm{S} 36^{\circ} 54^{\prime} 28.3^{\prime \prime} \mathrm{W} ; 10^{\circ} 21^{\prime} 35.3^{\prime \prime} \mathrm{S} 36^{\circ} 54^{\prime} 27.9^{\prime \prime} \mathrm{W}$ \\
\hline EPF48-52 & 5 & Moita Bonita & $\begin{array}{l}10^{\circ} 33^{\prime} 50.8^{\prime \prime} \mathrm{S} 37^{\circ} 22^{\prime} 27.8^{\prime \prime} \mathrm{W} ; 10^{\circ} 33^{\prime} 50.5^{\prime \prime} \mathrm{S} 37^{\circ} 22^{\prime} 26.8^{\prime \prime} \mathrm{W} ; 10^{\circ} 33^{\prime} 50.0^{\prime \prime} \mathrm{S} 37^{\circ} 22^{\prime} 25.7^{\prime \prime} \mathrm{W} ; 10^{\circ} 33^{\prime} 49.3^{\prime \prime} \mathrm{S} 37^{\circ} 22^{\prime} 26.5^{\prime \prime} \mathrm{W} ; 10^{\circ} 33^{\prime} 48.6^{\prime \prime S} \\
\end{array}$ \\
\hline EPF53-57 & 5 & Muribeca & 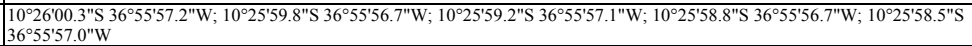 \\
\hline EPF58-72 & 15 & Pirambu & 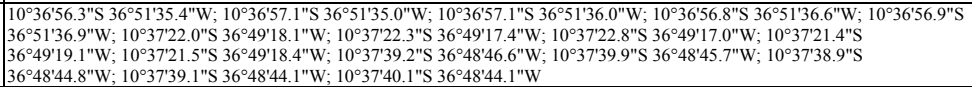 \\
\hline EPF73-80 & 8 & Salgado & 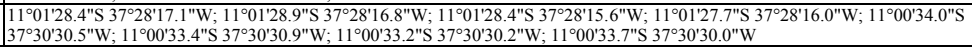 \\
\hline$\overline{\text { EPF81-85 }}$ & 5 & Santo Amaro das Brotas & $\begin{array}{l}10^{\circ} 48^{\prime 2} 24.8^{\prime \prime S} 37^{\circ} 00^{\prime} 24.4^{\prime \prime} \mathrm{W} ; 0^{\circ} 48^{\prime} 26.1^{\prime \prime} \mathrm{S} 37^{\circ} 00^{\prime} 24.7^{\prime \prime} \mathrm{W} ; 10^{\circ} 48^{\prime} 26.3^{\prime \prime} \mathrm{S} 37^{\circ} 00^{\prime} 23.5^{\prime \prime} \mathrm{W} ; 10^{\circ} 48^{\prime} 26.0^{\prime \prime} \mathrm{S} 37^{\circ} 00^{\prime} 22.7^{\prime \prime W} ; 10^{\circ} 48^{\prime} 25.5^{\prime \prime S} \\
\end{array}$ \\
\hline EPF86-100 & 15 & São Cristóvão & 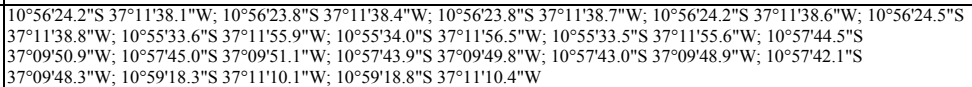 \\
\hline
\end{tabular}

$\mathrm{N}=$ number of plants.

\section{DNA extraction and polymerase chain reaction (PCR)-ISSR amplification}

Samples of $300 \mathrm{mg}$ young leaves were used for DNA extraction, according to procedures described by Doyle and Doyle (1990), with modifications. After preheating at $65^{\circ} \mathrm{C}, 1 \mathrm{~mL} 2 \% \mathrm{CTAB}$ extraction buffer $(5 \mathrm{M} \mathrm{NaCl}, 1 \mathrm{M}$ Tris-HCl, $\mathrm{pH}$ 8.0, 0.5 M EDTA) and $2 \%$ PVP were added to the powdered material. Samples were incubated at $65^{\circ} \mathrm{C}$ for $60 \mathrm{~min}$, inverting the tubes every $20 \mathrm{~min}$. Subsequently, $800 \mu \mathrm{L}$ chloroform/isoamyl alcohol (24:1) was added, followed by $500 \mu \mathrm{L}$ ice-cold isopropanol, and incubated overnight at $-20^{\circ} \mathrm{C}$. The precipitate was subjected to two rinses with $70 \%$ ethanol. After drying, DNA was resuspended in $100 \mu \mathrm{L}$ TE buffer (100 mM Tris-HCl, pH 7.4, $1 \mathrm{mM}$ EDTA). Samples were subjected to purification by adding $50 \mu \mathrm{L}$ of $7.5 \mathrm{M}$ ammonium acetate and $200 \mu \mathrm{L}$ absolute ethanol. The precipitate was washed with $70 \%$ ethanol and resuspended in $100 \mu \mathrm{L} \mathrm{TE}$ buffer.

DNA quantification was performed using a NanoDrop 2000c spectrophotometer (Thermo Fisher Scientific, Wilmington, DE, USA), and samples were diluted to $10 \mathrm{ng} / \mu \mathrm{L}$. The ISSR primers used in this study were obtained from Eurofins MWG Operon (Operon Technologies, Louisville, KY, USA) and Invitrogen (Thermo Fisher Scientific, Carlsbad, CA, USA). Eight ISSR primers (Table 2) were tested by PCR. Reactions were performed in a final volume of $20 \mu \mathrm{L}$ containing $1 \mathrm{X}$ Taq buffer (10 mM Tris-HCl, $\mathrm{pH} 8.8,50 \mathrm{mM} \mathrm{KCl}, 1 \%$ Triton-X-100 and $1.6 \mathrm{mM} \mathrm{MgCl}$ ), $2.5 \mathrm{mM}$ dNTP, 25 pmol primer, $10 \mathrm{ng}$ genomic DNA, and $1 \mathrm{U}$ Taq DNA polymerase (Neotaq).

Tabela 2. ISSR primers, their sequence, annealing temperature, and the amplified products used for genetic diversity analysis of Eplingiella fruticosa.

\begin{tabular}{l|l|c|c|c|c}
\hline Primer name & Sequence (5'-3') & Length (bp) & Annealing temperature $\left({ }^{\circ} \mathrm{C}\right)$ & Total number of bands & $\%$ Polymorphism \\
\hline ISSR4 & CAC ACA CAC ACA AC & $430-1315$ & 50.0 & 10 & $100 \%$ \\
\hline ISSR6 & CAC ACA CAC ACA AG & $300-1220$ & 50.0 & 9 & $100 \%$ \\
\hline ISSR7 & CAC ACA CAC ACA GT & $300-1220$ & 50.0 & 9 & $100 \%$ \\
\hline UBC809 & AGA GAG AGA GAG AGA GG & $327-1200$ & 57.5 & 9 & $100 \%$ \\
\hline UBC815 & CTC TTC TCT CTC TCT CTG & $630-1340$ & 47.6 & 8 & $100 \%$ \\
\hline UBC817 & CAC ACA CAC ACA CAC AA & $410-1235$ & 50.3 & 8 & $100 \%$ \\
\hline UBC835 & AGA GAG AGA GAG AGA GYC & $250-1240$ & 50.2 & $10 \%$ \\
\hline UBC851 & GTG TGT GTG TGT GTG TYG & $370-1350$ & 49.2 & & 100 \\
\hline
\end{tabular}


PCR amplifications were performed using a ProFlex PCR thermocycler (Thermo Fisher Scientific, Applied Biosystems, Foster City, CA, USA), where samples were initially denatured at $95^{\circ} \mathrm{C}$ for $5 \mathrm{~min}$, followed by 35 amplification cycles. In each cycle, denaturation was performed at $94^{\circ} \mathrm{C}$ for $50 \mathrm{~s}$, annealing at specific temperature for each primer used (Table 2) for $50 \mathrm{~s}$, and extension at $72^{\circ} \mathrm{C}$ for $1 \mathrm{~min}$, followed by a final extension at $72^{\circ} \mathrm{C}$ for $10 \mathrm{~min}$, and cooling at $4{ }^{\circ} \mathrm{C}$. Amplification products were subjected to $2 \%$ agarose gel electrophoresis, stained with ethidium bromide, visualized under ultraviolet light, and documented in Gel Doc L-pix HE (Loccus Biotecnologia).

\section{Data analysis}

Only clearly visible bands were used in the analysis and interpretation of the gels. Amplified DNA fragments were analyzed for the presence (1) or absence (0) of equal sized bands, and a binary matrix was constructed. Based on this matrix, the coefficient of the Jaccard similarity between each pair of individuals was calculated (Jaccard, 1908). The genetic distance was used to construct a dendrogram by the neighbor-joining method, using the MEGA7 software. The Shannon index (I), the genetic diversity of Nei/heterozygosity $\left(H_{\mathrm{E}}\right)$, and the polymorphic information content (PIC) were calculated using the GENALEX 6.5 software (Peakall and Smouse, 2012).

\section{RESULTS}

High polymorphism level was detected using the ISSR markers among the 100 plants of E. fruticosa in the State of Sergipe, Brazil. The locations of the bands can be visualized in the image generated by the photo documentation of the agarose gel (Figure 2). Eight primers were selected, and they were all polymorphic, since they showed good amplification pattern, with 72 amplified bands, ranging from 8 (UBC809, UBC817, and UBC835) to 11 (UBC815), and a mean of nine bands per primer (Table 2).

By using the cluster analysis method, three groups were formed from the genetic distances between plants (Figure 3). Group I consisted of 50 plants, mainly from the municipalities of Areia Branca, Estância, Japaratuba, Moita Bonita, Pirambu, and Salgado; Group II was formed by 21 plants, with nine representatives from the municipality of Itaporanga d'Ajuda, and 13 representatives from other municipalities; Group III was formed by 29 plants, mainly representatives from the municipalities of Malhada dos Bois and São Cristóvão. Plants collected in the municipalities of Muribeca and Santo Amaro das Brotas were equally distributed between the groups.

The genetic distances between the 100 plants of E. fruticosa are present in Table 3. The smallest genetic distance (0.250) was observed between plants EPF94 and EPF96, both from São Cristóvão, representing the genetically closest individuals among all the evaluated pairs. Individuals EPF50 (Moita Bonita) and EPF96 (São Cristóvão) presented the greatest genetic distance (0.9778) among the evaluated plants. Among all combinations of individuals, $9.23 \%$ had genetic distances between 0.250 and 0.500 . Conversely, $49.92 \%$ of the combinations presented genetic distances between 0.500 and 0.750 , and $40.85 \%$ of the combinations had a genetic distance greater than 0.750 , representing the most genetically distant plants.

Genetics and Molecular Research 16 (3): gmr16039749 


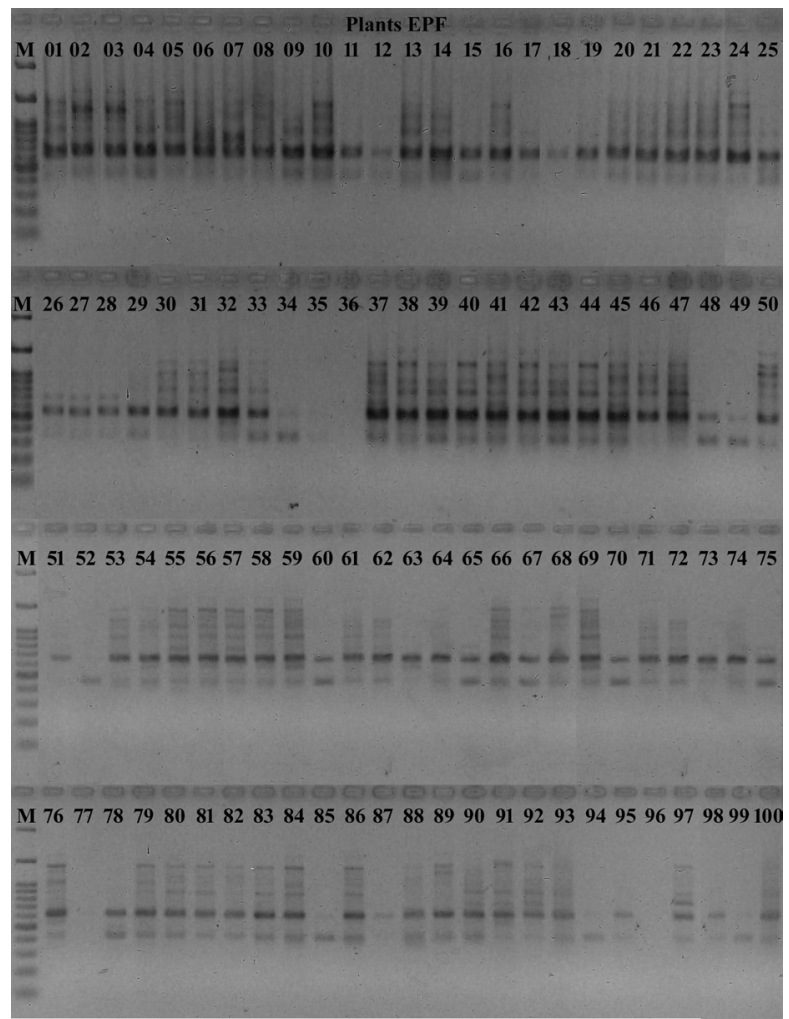

Figure 2. Agarose gels showing the electrophoretic profiles of the inter-simple sequence repeat markers amplified using the primer UBC817 in 100 Eplingiella fruticosa plants from different municipalities of the State of Sergipe, Brazil. Lane M: 100-bp molecular weight marker.

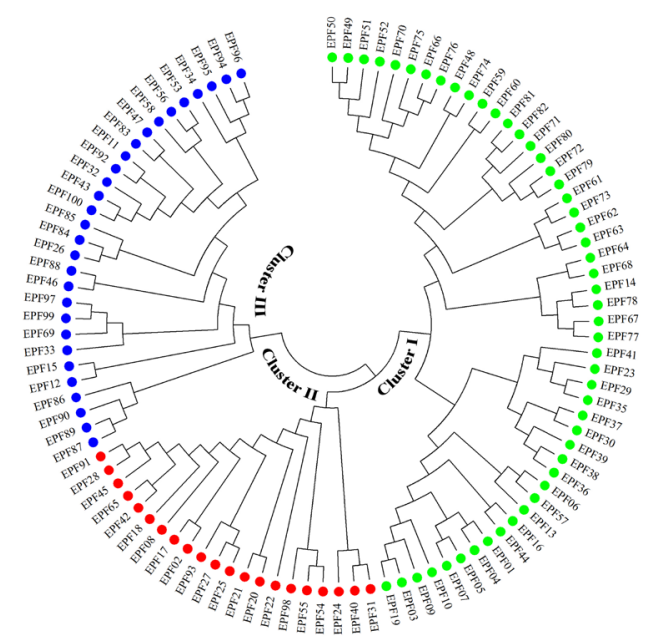

Figure 3. Dendrogram generated by the neighbor-joining analysis of the Jaccard's coefficients of similarity for 100 Eplingiella fruticosa plants from different municipalities of the State of Sergipe, Brazil.

Genetics and Molecular Research 16 (3): gmr16039749 
Table 3. Pairs of genotypes that presented extreme values of small and great genetic distance (d) based on the Jaccard's coefficient of similarity for eight ISSR markers in 100 individuals of Eplingiella fruticosa.

\begin{tabular}{|c|c|c|c|c|}
\hline \multirow[t]{2}{*}{ Order } & \multicolumn{2}{|c|}{ Low genetic distance } & \multicolumn{2}{|c|}{ High genetic distance } \\
\hline & Pairs of genotypes & $\mathrm{d}$ & Pairs of genotypes & $\mathrm{d}$ \\
\hline 1 & EPF94 x EPF96 & 0.2500 & EPF50 x EPF96 & 0.9778 \\
\hline 2 & EPF62 x EPF63 & 0.2821 & EPF50 x EPF94 & 0.9778 \\
\hline 3 & EPF66 x EPF76 & 0.2857 & EPF34 x EPF41 & 0.9767 \\
\hline 4 & EPF36 x EPF38 & 0.3095 & EPF61 x EPF97 & 0.9762 \\
\hline 5 & EPF75 x EPF76 & 0.3095 & EPF05 x EPF97 & 0.9750 \\
\hline 6 & EPF87 x EPF89 & 0.3103 & EPF59 x EPF94 & 0.9750 \\
\hline 7 & EPF54 x EPF55 & 0.3235 & EPF16 x EPF97 & 0.9730 \\
\hline 8 & EPF11 x EPF92 & 0.3333 & EPF43 x EPF81 & 0.9722 \\
\hline 9 & EPF36 x EPF39 & 0.3333 & EPF47 x EPF81 & 0.9722 \\
\hline 10 & EPF43 x EPF100 & 0.3333 & EPF54 x EPF97 & 0.9722 \\
\hline 11 & EPF70 x EPF75 & 0.3333 & EPF63 x EPF97 & 0.9722 \\
\hline 12 & EPF50 x EPF59 & 0.3409 & EPF16 x EPF28 & 0.9714 \\
\hline 13 & EPF70 x EPF74 & 0.3415 & EPF48 x EPF96 & 0.9714 \\
\hline 14 & EPF38 x EPF40 & 0.3421 & EPF09 x EPF97 & 0.9706 \\
\hline$\overline{15}$ & EPF71 x EPF72 & 0.3500 & EPF34 x EPF86 & 0.9706 \\
\hline 16 & EPF59 x EPF60 & 0.3514 & EPF51 x EPF97 & 0.9706 \\
\hline 17 & EPF14 x EPF78 & 0.3529 & EPF48 x EPF94 & 0.9697 \\
\hline 18 & EPF64 x EPF78 & 0.3529 & EPF01 x EPF83 & 0.9688 \\
\hline 19 & EPF66 x EPF67 & 0.3571 & EPF01 x EPF97 & 0.9688 \\
\hline 20 & EPF09 x EPF10 & 0.3611 & EPF14 x EPF94 & 0.9688 \\
\hline
\end{tabular}

The Shannon index ranged from 0.032 to 0.693 , with a mean of 0.419 per primer. The $H_{\mathrm{E}}$ ranged from 0.010 to 0.500 , with a mean value of 0.267 . The mean PIC was 0.253 .

\section{DISCUSSION}

Genetic diversity between the different E. fruticosa plants collected in the State of Sergipe and analyzed using ISSR markers can be considered as intermediate. The 100 plants analyzed in this study were distributed into three distinct groups according to genetic distance. The high similarity observed between the plants from distinct regions is probably due to crosses between plants of different areas. It is believed that animals and anthropic activities helped the dispersion of seeds from one region to another, which allowed transferring genetic information between regions, considering that all the collections were carried out in sites with red, yellow podzol soils that presented texture of rough surface horizon, all located near the highways.

To date, no specific studies on the reproductive strategies of $E$. fruticosa have been reported. Each plant has several inflorescences, and it is suggested that the pollination of the flowers occurs by insects. Due to the agglomeration of plants in the same location, pollinating insects usually visit inflorescences of the same plant and nearby plants. The low genetic diversity identified in this study may be associated with the cross between related individuals (Jennings et al., 2016).

Despite the absence of studies on the genetic diversity of $E$. fruticosa, moderate difference between the chemical compounds was observed in a survey of some studies that analyzed the chemical composition of the essential oil of this species, collected specifically in the region of São Cristóvão-SE (Menezes et al., 2007, Silva et al., 2008, Franco et al., 2011a,b). Likewise, the results of the present study indicate that the plants collected in this region had reduced genetic variability and were predominantly grouped in cluster III. From this, it can be suggested that the chemical composition of the essential oils of E. fruticosa is strongly influenced by genetic factors. The relation between chemical groups and genetic variability may assist, with better efficiency, the establishment of strategies for conservation of the species and use in future breeding programs.

Genetics and Molecular Research 16 (3): gmr16039749 
According to the dendrogram (Figure 3), a tendency of grouping was observed concerning the geographic origin, except for the plants collected in Muribeca and Santo Amaro das Brotas, which are distributed in the three groups. Subgroup 1 of group I consisted of all the plants collected in Moita Bonita and Salgado, besides $80 \%$ of the plants collected in Pirambu. Group III consisted of $78 \%$ of the plants collected in São Cristóvão and $100 \%$ of the plants collected in Malhada dos Bois.

The Shannon index observed in the present study $(I=0.42)$ and the genetic diversity of Nei $\left(H_{\mathrm{E}}=0.267\right)$, which measures the genetic variability and estimates the variation among individuals, were higher than the genetic diversity reported in Calanthe tsoongiana $\left(H_{\mathrm{E}}=0.183\right.$, I $=0.271)\left(\right.$ Qian et al., 2013), Stipa bungeana $\left(H_{\mathrm{E}}=0.079, \mathrm{I}=0.327\right)($ Yu et al., 2014), and Blysmus sinocompressus $\left(H_{\mathrm{E}}=0.158, \mathrm{I}=0.143\right)$ (Hu et al., 2016), being these plants strictly endemic. This indicates that $E$. fruticosa has not reached critical levels of genetic diversity loss yet.

Mean PIC was of 0.253 . PIC indicates how much the markers can detect polymorphic information in studies of genetic diversity. According to Botstein et al. (1980), the markers used in this study can be classified as moderately informative. Similar results were obtained for the genetic diversity of Hancornia speciosa (Costa et al., 2015) and Varronia curassavica (Brito et al., 2016) using ISSR markers, possibly due to the alleles shared among the individuals evaluated.

Despite the lack of information on the genetic diversity of species of the genus Eplingiella, the present results are in agreement with those found in some studies carried out in natural populations of Lamiaceae species in the world. When evaluating the genetic diversity of natural populations of Salvia miltiorrhiza in different regions of China, Song et al. (2010) found $100 \%$ polymorphism using five ISSR primers and 110 bands. Similarly, the use of 20 ISSR markers was efficient in the discrimination of Ocimum, species with $99.58 \%$ polymorphism (Kumar et al., 2016). Other studies have identified intermediate diversity in the populations studied, such as genetic diversity in Leonurus cardiac populations, with $86.84 \%$ of polymorphic bands (Khadivi-Khub and Soorni, 2014), and in Satureja rechingeri populations sampled in Iran, with $79 \%$ of polymorphic bands (Hadian et al., 2015), both using ISSR markers.

The genetic diversity of E. fruticosa plants of the State of Sergipe was considered as intermediate. Nevertheless, considering the environmental degradation of the areas of natural occurrence of the species, strategies for plant conservation must be adopted. This is the first study on the genetic diversity of E. fruticosa, and the results observed here help understand the distribution of genetic diversity of the species and provide important information for the development of collection strategies. When implementing a germplasm conservation program, plants of the three groups should be prioritized to conserve the maximum variability. Moreover, to enrich the genetic diversity of the collection, the markers used in the present study may be applied during the selection process and introduction of new accessions from other Brazilian regions.

\section{Conflicts of interest}

The authors declare no conflict of interest.

\section{ACKNOWLEDGMENTS}

The authors thank CNPq, FAPITEC/SE, CAPES, and Embrapa Tabuleiros Costeiros for their support for this study.

Genetics and Molecular Research 16 (3): gmr16039749 


\section{REFERENCES}

Alves MF, Nizio DAC, Brito FA, Sampaio TS, et al. (2016). Analysis of genetic diversity of a native population of Myrcia lundiana Kiaersk. plants using ISSR markers. Genet. Mol. Res. 15: 1-10. https://doi.org/10.4238/gmr15049198

Baruah J, Gogoi B, Das K, Ahmed NM, et al. (2017). Genetic diversity study amongst Cymbopogon species from NEIndia using RAPD and ISSR markers. Ind. Crops Prod. 95: 235-243. https://doi.org/10.1016/j.indcrop.2016.10.022

Botstein D, White RL, Skolnick M and Davis RW (1980). Construction of a genetic linkage map in man using restriction fragment length polymorphisms. Am. J. Hum. Genet. 32: 314-331.

Brito FA, Nizio DAC, Silva AVC, Diniz LEC, et al. (2016). Genetic diversity analysis of Varronia curassavica Jacq. accessions using ISSR markers. Genet. Mol. Res. 15: 1-10. https://doi.org/10.4238/gmr.15038681

Celestino RS, Zucchi MI, Pinheiro JB, Campos JB, et al. (2015). Molecular and chemical characterization of vetiver, Chrysopogon zizanioides (L.) Roberty, germplasm. Genet. Mol. Res. 14: 9452-9468. https://doi.org/10.4238/2015. August.14.9

Costa DF, Vieira FA, Fajardo CG and Chagas KPT (2015). Diversidade genética e seleção de iniciadores ISSR em uma população natural de Mangaba (Hancornia speciosa Gomes) (Apocynaceae). Rev. Bras. Frutic. 37: 970-976. https:// doi.org/10.1590/0100-2945-246/14

Dobeš C, Konrad H and Geburek T (2017). Potential population genetic consequences of habitat fragmentation in central European forest trees and associated understorey species - An introductory survey. Diversity (Basel) 9: 1-24. https:// doi.org/10.3390/d9010009

Doyle JJ and Doyle JL (1990). Isolation of plant DNA from fresh tissue. Focus 12: 13-15.

El-Amin HKA and Hamza NB (2016). Comparative analysis of genetic structure and diversity of Sorghum (Sorghum bicolor L.) local farmer's varieties from Sudan. J. Adv. Biol. Biot. 5: 1-10. https://doi.org/10.9734/JABB/2016/22735

Erbano M, Schühli GS and Santos EP (2015). Genetic variability and population structure of Salvia lachnostachys: implications for breeding and conservation programs. Int. J. Mol. Sci. 16: 7839-7850. https://doi.org/10.3390/ ijms 16047839

Franco CRP, Alves PB, Andrade DM, Jesus HCR, et al. (2011a). Essential oil composition and variability in Hyptis fruticosa. Br. J. Pharmacol. 21: 24-32. https://doi.org/10.1590/S0102-695X2011005000034

Franco CRP, Antoniolli ÂR, Guimarães AG, Andrade DM, et al. (2011b). Bioassay-guided evaluation of antinociceptive properties and chemical variability of the essential oil of Hyptis fruticosa. Phytother. Res. 25: 1693-1699. https://doi. org/10.1002/ptr.3455

Hadian J, Karami A, Azizi A and Khadivi-Khub A (2015). Ubiquitous genetic diversity among and within wild populations of Satureja rechingeri assessed with ISSR markers. Plant Syst. Evol. 301: 923-930. https://doi.org/10.1007/s00606$\underline{014-1126-5}$

Hu Y-P, Bao R, Shi L, Wang J-K, et al. (2016). Analysis of population structure of Blysmus sinocompressus in the Qilian Mountains by ISSR markers. Aquat. Bot. 134: 54-60. https://doi.org/10.1016/j.aquabot.2016.06.011

Jaccard P (1908). Nouvelles recherches sur la distribution florale. Bull. Soc. Vaud. Sci. Nat. 44: 223-270.

Jennings H, Wallin K, Brennan J, Valle AD, et al. (2016). Inbreeding, low genetic diversity, and spatial genetic structure in the endemic Hawaiian lobeliads Clermontia fauriei and Cyanea pilosa ssp. longipedunculata. Conserv. Genet. 17: 497-502. https://doi.org/10.1007/s10592-015-0785-2

Khadivi-Khub A and Soorni A (2014). Comprehensive genetic discrimination of Leonurus cardiaca populations by AFLP, ISSR, RAPD and IRAP molecular markers. Mol. Biol. Rep. 41: 4007-4016. https://doi.org/10.1007/s11033-014-3269-4

Kumar A, Mishra P, Baskaran K, Shukla AK, et al. (2016). Higher efficiency of ISSR markers over plastid $p s b A$-trnH region in resolving taxonomical status of genus Ocimum L. Ecol. Evol. 6: 7671-7682. https://doi.org/10.1002/ece3.2483

de Lima AC, Paixão MS, Melo M, de Santana MT, et al. (2013). Orofacial antinociceptive effect and antioxidant properties of the hydroethanol extract of Hyptis fruticosa salmz ex Benth. J. Ethnopharmacol. 146: 192-197. https://doi. org/10.1016/j.jep.2012.12.031

Menezes IAC, Marques MS, Santos TC, Dias KS, et al. (2007). Antinociceptive effect and acute toxicity of the essential oil of Hyptis fruticosa in mice. Fitoterapia 78: 192-195. https://doi.org/10.1016/j.fitote.2006.11.020

Peakall R and Smouse PE (2012). GenAlEx 6.5: genetic analysis in Excel. Population genetic software for teaching and research--an update. Bioinformatics 28: 2537-2539. https://doi.org/10.1093/bioinformatics/bts460

Qian X, Wang C-X and Tian M (2013). Genetic diversity and population differentiation of Calanthe tsoongiana, a rare and endemic orchid in China. Int. J. Mol. Sci. 14: 20399-20413. https://doi.org/10.3390/ijms141020399

Sampaio TS, Nizio DAC, White LAS, Melo JO, et al. (2016). Chemical diversity of a wild population of Myrcia ovata Cambessedes and antifungal activity against Fusarium solani. Ind. Crops Prod. 86: 196-209. https://doi.org/10.1016/j. indcrop.2016.03.042

Genetics and Molecular Research 16 (3): gmr16039749 
Santos CP, Pinto JAO, Santos CA, Cruz EMO, et al. (2016). Harvest time and geographical origin affect the essential oil of Lippia gracilis Schauer. Ind. Crops Prod. 79: 205-210. https://doi.org/10.1016/j.indcrop.2015.11.015

Santos MRV, Carvalho AA, Medeiros IA, Alves PB, et al. (2007). Cardiovascular effects of Hyptis fruticosa essential oil in rats. Fitoterapia 78: 186-191. https://doi.org/10.1016/j.fitote.2006.11.009

Silva WJ, Dória GAA, Maia RT, Nunes RS, et al. (2008). Effects of essential oils on Aedes aegypti larvae: alternatives to environmentally safe insecticides. Bioresour. Technol. 99: 3251-3255. https://doi.org/10.1016/j.biortech.2007.05.064

Song Z, Li X, Wang H and Wang J (2010). Genetic diversity and population structure of Salvia miltiorrhiza Bge in China revealed by ISSR and SRAP. Genetica 138: 241-249. https://doi.org/10.1007/s10709-009-9416-5

Yousefi V, Najaphy A, Zebarjadi A and Safari H (2015). Molecular characterization of Thymus species using ISSR markers. J. Anim. Plant Sci. 25: 1087-1094.

Yu J, Jing ZB and Cheng JM (2014). Genetic diversity and population structure of Stipa bungeana, an endemic species in Loess Plateau of China, revealed using combined ISSR and SRAP markers. Genet. Mol. Res. 13: 1097-1108. https:// doi.org/10.4238/2014.February.20.11

Genetics and Molecular Research 16 (3): gmr16039749 